Jurnal Administrasi Publik (Public Administration Journal), 10(2) December 2020

ISSN2088-527X (Print) ISSN2548-7787 (Online) DOI: https://doi.org/10.31289/jap.v10i2.3541

Jurnal Administrasi Publik (Public Administration Journal)

Available online http://ojs.uma.ac.id/index.php/iap

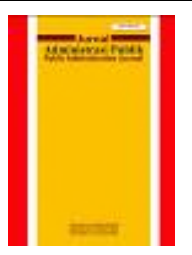

\title{
Analysis of the Effect of Adaptive Competence Customer Relation Officer on Service Recovery Performance
}

\author{
Ayu Adriana Putri* \& Rachma Fitriati
}

\author{
University of Indonesia, Indonesia
}

Received: February 27, 2020; Reviewed: May 08, 2020; Accepted: July 03, 2020

*Email: adr_putri@yahoo.com

\begin{abstract}
The purpose of this study was to analyze the effect of the adaptive ability of customer relation officers in service recovery performance in the One Stop Integrated Services and Investment Office of the Special Capital Region of Jakarta (DKI). The method used in this research is quantitative. Sources of data were taken from informants, namely customer relation officers who were directly involved in the recommendation service for Building Use Rights over Land Management Rights, namely 50 respondents. The data collection technique was carried out by conducting initial interviews and distributing and filling out questionnaires. The results of the study found that culture competence, self management, social capacity, self-efficacy recovery and organizational system recovery, affect service recovery performance while informational fairness has no effect on service recovery performance of customer relation officers. Keywords: Adaptive competence, Service recovery, Customer relation officers
\end{abstract}

How to Cite: Putri, A.A \& Fitriati, R (2020). Analysis of the Effect of Adaptive Competence Customer relation officer on Service recovery Performance, Jurnal Administrasi Publik (Public Administration Journal). 10(2): 164-173 


\section{PRELIMINARY}

Governor of Jakarta, 2012-2014 period Ir. H. Joko Widodo had an idea to make licensing easier and less complicated in Jakarta. This idea arises because public services are the most easily assessed by the community, so if you want to change the face of the bureaucracy which is known to be bad, the improvement that is most easily felt by the community as service recipients is to improve public services. One year later, namely in 2015 the One Stop Integrated Service Agency (OSISA) was formed. The formation of the agency is based on (Indonesia, 2013), which was inaugurated by Basuki Tjahja Purnama, the Governor of DKI Jakarta for the 2014-2017 period. OSISA was formed to become the front liner in licensing services for Jakarta residents. (Yusriadi, 2018) explained that the existence of SISA, the service provider apparatus must be properly arranged, updated and improved to change the image of the apparatus which was previously known to be slow (due to long bureaucracy) and not transparent to be effective in accordance with the objectives of public services. Currently, OSISA has changed its name nationally to the One Stop Investment and Integrated Services Service (OSIISS) in accordance with the Minister of Home Affairs Regulation Number 100 of 2016 concerning the Nomenclature Guidelines for the Investment Service and One Stop Integrated Services.

OSIISS of DKI Jakarta Province is always committed to providing excellent public services. Various service innovations presented by OSIISS are solely carried out to fulfill the basic needs and civil rights of every citizen to prime public services in Jakarta. In order to maximize the public services provided to the citizens of Jakarta, OSIISS has made several innovations, one of which is the use of front liner officers, namely customer relation officers, hereinafter referred to as CRO. It should be noted that previously face-to-face services at OSIISS DKI Jakarta Province were served directly by the State Civil Apparatus (SCA), but in order to improve the professionalism of the DKI Jakarta Provincial SCA and maximize the performance of public services. So OSIISS of DKI Jakarta Province adopted several service systems from the private sector, namely the use of front liners, so that SCA only did technical things, not administration anymore.

During their time as front liner, CRO officers experienced several obstacles, especially in carrying out service recovery. Service recovery activities are an effort made to treat customer disappointment for service that is not (Atmadjati, 2018). Dealing directly is certainly different from indirect, especially dealing with consumers, in this case the applicant who has problems, such as experiencing a service failure or service failure. The higher emotional level possessed by the applicant means that CRO officers must have better resilience, when compared to officers who do not come face to face with the applicant. As a consequence of service failure, the organization makes an effective service recovery policy an integral part so that consumers take the initiative to remember how the company responds, (Kotler, 2017) CRO as the vanguard at OSIISS must prepare itself if a failure in service occurs. CRO must have the ability to handle or respond to service failures to requesters. The right attitude and actions in the context of service recovery need to be implemented.

Service recovery evaluation is often carried out from the applicant's point of view. Various studies have always looked at the effectiveness of service recovery carried out from the point of view of service recipients, as if ignoring the point of view of the service provider, namely the service officer in this study is a CRO. In terms of making policies, it will be more effective to pay attention to both sides, because current services are not only providing services, but also paying attention to quality and analyzing things that can affect the quality of the service. Based on these 
considerations, it is necessary to pay attention to the side of the service officer. The ability of CRO in service is of course something that must be considered, but in the process it is necessary to analyze what things can affect the service performance of a service officer, especially in service recovery.

The implementation of service recovery itself is something that must be done by agencies or companies, especially private companies that are profit-oriented so as not to lose consumers, but in terms of public services, although not profitoriented, service recovery still needs to be carried out. Remembering to achieve quality public services and change the impression of public services that are known to be bad for the better. Service recovery is defined as the actions taken by the organization in response to a service failure (Zeithaml, V. A. Bitner, 2000).

In order to ideally achieve the expected service recovery. The adaptive ability of CRO in providing special services to applicants who experience service failure certainly needs to be a concern, therefore this study focuses on the factors that affect the adaptive ability of CRO in service recovery. Various discussions about human resources, one of which is the adaptability of employees to increase their productivity. Adaptive competence or adaptive behavior is the employee's capacity to adapt to the work environment. An employee must be able to adapt to his work environment so that the employee can move and perform optimally and comfortably. Adaptation is a process that must be undertaken by every employee, then by going through this process it will determine the performance of an employee at the beginning of the work period. In some cases, an employee's adaptive behavior determines the future of an employee in an organization. If the employee is able to survive the adaptation then his career will be good in the future.
According to (Schindehutte \& Morris, 2001) adaptation can be defined as the actions of entrepreneurial entrepreneurs and their teams in processing information inputs from their environment and making quick adjustments. So that the adaptive behavior of an employee is an act of processing input information from the environment, both the work environment and outside of work, then making adjustments quickly.

(McQuilken, Robertson, Abbas, \& Polonsky, 2020) reveal things that affect the adaptive ability of health workers in Qatar to service recovery performance as follows:

1. Cultural competence or cultural intelligence is the ability to adapt to the diverse cultural needs of customers. Cultural intelligence is one specific form of interpersonal intelligence (Sopan Adrianto, 2019)

2. Self management, involving the management of feelings and moods of employees. which is the dimension of emotional intelligence. (Gantina, 2011) defines self-management as a procedure in which individuals manage their own behavior.

3. Social capacity, the ability to manage and evaluate emotional states based on social cues

4. Informational fairness, providing clear, honest and accurate information. Informational fairness or information fairness is related to the explanation given regarding the results, (Sahadev, $S$., Purani, K., \& Malhotra, 2015) Recovery self-efficacy, reflecting belief in their ability to recover successfully.

The recommendation service for building use rights over land management rights, hereinafter referred to as recommendations for HGB over HPL, is one of the permits carried out by OSIISS Jakarta. This type of licensing is one of the licenses that contributed the highest to regional income in Jakarta, especially in 2017. The high and large fees obtained from the HGB 
recommendation permit above the HPL are very meaningful for Jakarta, therefore it is necessary to pay attention to tips so that the income from the recommendation HGB above HPL can be obtained maximally.

From the results of the initial interviews conducted by researchers with CRO officers, it was revealed that the effect of the OSIISS service recovery system or organizational service recovery system affected the attitude and service of CRO officers to problematic applicants. Then the results of the interview also revealed that self-management self-control affects CRO in dealing with applicants who have problems or are in an emotional state. Based on the literature, the researcher made the following operational concepts:

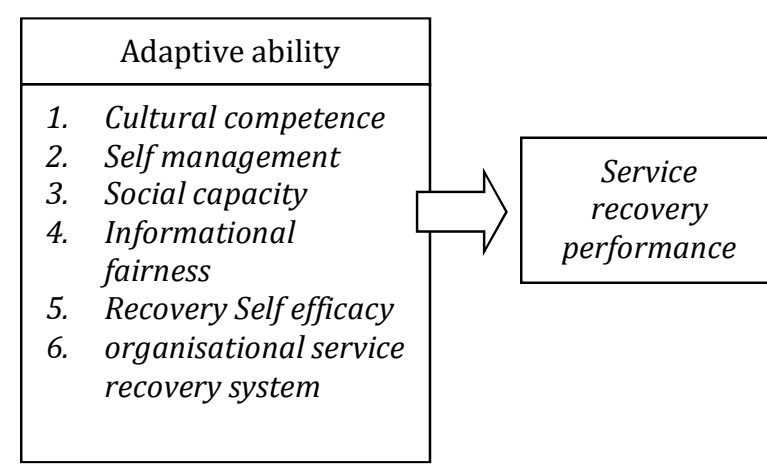

Figure1. Operational concept

Based on Figure 1, that the concept of adaptive competence in this study consists of six variables consisting of, cultural competence, self-management, social capacity, information justice, self-efficacy and organizational improvement systems. Then the hypothesis proposed in this study is as follows:

a) Cultural Competence

H0: There is no effect from the implementation of the adaptive capacity of CRO officers; cultural competence with service recovery performance recommendations for HGB recommendations above HPL.
H1: There is an effect of the implementation of the adaptive capacity of CRO officers; cultural competence towards service recovery performance, recommendation of HGB above HPL.

b) Self-management

H0: There is no effect from the implementation of the adaptive capacity of CRO officers; self-management of service recovery performance recommendations for HGB over HPL

H1: There is an effect of the implementation of the adaptive capacity of CRO officers; self-management of service performance recovery service recommendations HGB over HPL

c) Social Capacity

H0: There is no effect from the implementation of the adaptive capacity of CRO officers; social capacity for service performance recovery, recommended HGB services above HPL

H1: There is an effect of the implementation of the adaptive capacity of CRO officers; social capacity for service performance recovery, recommended HGB services above HPL.

d) Informational Fairness

H0: There is no effect from the implementation of the adaptive capacity of CRO officers; informational fairness on service performance recovery services for HGB recommendations over HPL.

H1: There is an effect of the implementation of the adaptive capacity of CRO officers; informational fairness on service performance recovery services for HGB recommendations over HPL.

e) Recovery Self-efficacy

H0: There is no effect from the implementation of the adaptive capacity of CRO officers; recovery self-efficacy towards service performance recovery service recommendations HGB over HPL.

H1: There is an effect of the implementation of the adaptive capacity of CRO officers; recovery self-efficacy towards service performance recovery service recommendations HGB over HPL. 
f) Organizational Recovery System

H0: There is no effect from the implementation of the adaptive capacity of CRO officers; organizational recovery system for service performance recovery service recommendation of HGB over HPL.

H1: There is an effect of the implementation of the adaptive capacity of CRO officers; organizational recovery system for service performance recovery service recommendation of HGB over HPL.

\section{RESEARCH METHODS}

The research method used by the author is quantitative through a survey to determine what adaptive ability factors affect the service recovery performance of the CRO. Qualitative methods were used to identify factors that would affect the adaptive ability of CRO officers to their performance in performing service recovery.

The scoring in this study uses a Likert scale. In this study, each respondent, namely CRO, was given a questionnaire with positive statements regarding the assumptions and attitudes that influence CRO's adaptive competence in performing service recovery on HGB recommendation services over HPL. Respondents were asked to provide answers: "strongly agree" "agree" "disagree" "strongly disagree" and "irrelevant". Sampling was done using a total quota sampling technique. According to (Sugiyono, 2009) what is meant by total quota sampling is a sampling technique where the number of samples is the same as the population. The reason is because the population is less than 100. The respondents in this study were 50 people who served as CRO's. The data collection technique is done by distributing and filling out questionnaires. Data analysis carried out in this study through quantitative analysis using results with statistical tables with data management stages, namely data interpretation, data reduction, data preparation, checking the validity of data and drawing conclusions. Colton categorizes the strength of a relationship between two variables qualitatively as follows:

1. Value Interval $\mathrm{R} 0.00-0.25=$ no relationship / weak relationship

2. Interval value $\mathrm{R} 0.26-0.50=$ medium relationship

3. Interval value $\mathrm{R} 0.51-0.75=$ strong relationship

4. Interval value R $0.76-1.00=$ very strong / perfect relationship.

\section{RESULTS AND DISCUSSION}

Based on the results of the study, it is found that the strength of the relationship that is owned by cultural competence, selfmanagement, social capacity, recovery selfefficacy, organizational recovery system and informational fairness on service recovery performance. The results of the calculation of the value of the relationship strength or the $\mathrm{R}$ value can be seen in table 1.

Table 1 Calculation Results of Simple Linear Regression Variable Adaptive Ability to Dependent Variables Service recovery Performance CRO

\begin{tabular}{lllll}
\hline Adaptive ability CRO & $R$ & R square & Adjusted R Square & Std Error of the Estimate \\
\hline cultural competence & 0,528 & 0,279 & 0,264 & 1,855 \\
\hline self-management & 0,717 & 0,514 & 0,504 & 1,522 \\
\hline social capacity & 0,563 & 0,317 & 0,303 & 1,805 \\
\hline informational fairness & 0,201 & 0,04 & 0,020 & 2,139 \\
\hline recovery self-efficacy & 0,774 & 0,599 & 0,591 & 1,382 \\
\hline organizational recovery system & 0,723 & 0,522 & 0,512 & 1,509 \\
\hline 50 & & &
\end{tabular}

Source: Researcher's analysis results

Table 1 shows that the $\mathrm{R}$ value on cultural competence is 0.528 , meaning that the variable cultural competence has a strong relationship to service recovery 
performance because the $R$ value is between the interval 0.51-0.75. The coefficient of determination or the value of $\mathrm{R}$ Square on the cultural competence variable of CRO officers is 0.279 , which means that the regression model obtained can explain $27.9 \%$ of the variation in the dependent variable service performance recovery service performance recommendations HGB above HPL. While the rest $(100 \%-27.9 \%)$ is $72.1 \%$ explained by other variables outside of this study.

Based on table 1, it is obtained that the $R$ value in the self management variable is 0.717. This means that the selfmanagement variable has a strong relationship to service recovery performance because the $R$ value is between the interval 0.51-0.75. The coefficient of determination or the value of $\mathrm{R}$ Square on the self-management variable of CRO officers is 0.514 , which means that the regression model obtained can explain $51.4 \%$ of the variation in the dependent variable service recovery. While the rest $(100 \%-51.4 \%)$ is $48.6 \%$ explained by other variables outside of this study.

The strength of variable social capacity based on table 1 on service recovery performance is 0.563 , so it is categorized as having a strong relationship because the $R$ value is between the interval 0.51-0.75. The coefficient of determination or the value of $\mathrm{R}$ Square on the social capacity variable for CRO officers is 0.317 , which means that the regression model obtained can explain $31.7 \%$ of the variation in the dependent variable service recovery recommendation HGB above HPL. While the rest $(100 \%-31.7 \%)$ is $68.3 \%$ explained by other variables outside this study.

The relationship between the strength of the informational fairness variable on service recovery performance is 0.201 , so that the informational fairness variable is considered to have no relationship with service recovery performance. The coefficient of determination or the value of
$\mathrm{R}$ Square on the informational fairness variable is 0.04 , which means that the regression model obtained can explain 4\% of the variation in the dependent variable service recovery recommendations for HGB above HPL. While the rest $(100 \%-4 \%)$ is $96 \%$ explained by other variables outside this study.

The relationship between the power of variable recovery self-efficacy and service recovery performance is very strong. This is because the $\mathrm{R}$ value of the recovery self-efficacy variable is 0.774 $(0.76-1.00=$ very strong). The value of the coefficient of determination or the value of R Square on the adaptive ability of recovery self-efficacy of CRO officers is 0.599 , which means that the regression model obtained can explain $59.9 \%$ of the variation in the dependent variable service recovery recommendation HGB above HPL. While the rest $(100 \%-59.9 \%)$ is $40.1 \%$ explained by other variables outside of this study.

Variable organizational recovery system to service recovery performance has a strong relationship, because the value of $\mathrm{R}$ on the variable organizational recovery system is located in the interval $0.51-0.75$ which is equal to 0.723 . The coefficient of determination or the value of $\mathrm{R}$ Square on the organizational recovery system variable for CRO officers is 0.522 , meaning that the regression model obtained can explain $52.2 \%$ of the variation in the dependent variable service recovery. While the rest $(100 \%-52.2 \%)$ is $47.8 \%$ explained by other variables outside of this study.

\section{The Effect of Cultural Competence on Service Recovery Performance}

The value of $t$ calculated in Cultural Competence is 4,308 . On the basis of the conditions for acceptance of $\mathrm{H} 1$ is the value of $t$ count $>t$ critical, which in this section is 4.308> 2.01063, then the first $\mathrm{H} 1$ is declared acceptable. Based on the results of the ANOVA test data processing, the significance value shows a number of 0.000 , which means that the significance value is 
lower than 0.050. It can be concluded that the adaptive ability of CRO officers; cultural competence can affect the service recovery performance of HGB recommendations over HPL. Therefore, it can be concluded that $\mathrm{HO}$ is rejected and $\mathrm{H} 1$ is acceptable, namely the implementation of the adaptive ability of CRO officers; Cultural competence has an influence on service recovery performance. The coefficient of determination or the value of $\mathrm{R}$ Square on the adaptive ability of the CRO officers' cultural competence is 0.279 , which means that the regression model obtained can explain $27.9 \%$ of the variation in the dependent variable service recovery recommendations for HGB above HPL.

The results showed that cultural competence had a direct, positive and significant effect on service recovery performance of a CRO. This shows that the better a CRO's Cultural Competence is, the higher the service recovery performance is. When the HGB service fails above the HPL, the applicant makes a complaint and complaint to the CRO. The CRO process in treating the applicant according to cultural values so that the problem can be resolved very well. In addition, CRO officers used various sources to learn about how the different cultural backgrounds of the applicant for HGB recommendation over HPL so that it could have an impact on improving the service quality of HGB recommendations over HPL. The results of this study indicate that to improve service recovery performance, OSIISS must pay attention to the cultural competence factors of a CRO who are appropriate in handling applicants, especially in service recovery efforts.

The results of this study are consistent with the results of previous research conducted by (Wong, 2004) which states that Cultural Competence has a positive and significant effect on service recovery performance.

\section{The Influence of Self-Management on Service Recovery Performance}

The coefficient of determination or the value of $\mathrm{R}$ Square on the adaptive ability of self-management of CRO officers is 0.514 , which means that the regression model obtained can explain $51.4 \%$ of the variation in the dependent variable service recovery. that the regression model obtained can explain $27.9 \%$ of variations in the dependent variable service recovery recommendations HGB above HPL.

The $t$ value for self-management is 7,128 . Based on the results of the ANOVA test data processing, the significance value shows a number of 0.000 , which means that the significance value is lower than 0.050 . It can be concluded that the adaptive ability of CRO officers; Self-management can affect service recovery performance. The coefficient of determination or the value of $\mathrm{R}$ Square on the adaptive ability of the CRO officers' cultural competence is 0.279 , which means that the regression model obtained can explain $27.9 \%$ of variations in the dependent variable service recovery recommendations for HGB above HPL. Therefore, it can be concluded that $\mathrm{HO}$ is rejected and $\mathrm{H} 1$ is acceptable, namely the implementation of the adaptive capacity of CRO officers; Self-management has an influence on service recovery performance. The coefficient of determination or the value of $\mathrm{R}$ Square on the adaptive ability of the CRO officers' cultural competence is 0.279 meaning that the regression model obtained can explain $27.9 \%$ of the variation in the dependent variable service recovery recommendations for HGB above HPL.

This shows that the better selfmanagement a CRO has, the better the service recovery performance is given to applicants who experience service failure. In terms of self-management, a CRO makes a valuable contribution to the agency in efforts to improve the quality of service quality recommendations for HGB over HPL, so that it can have an impact on improving the quality of service for HGB 
recommendations over HPL. The results of this study indicate that in order to improve service recovery performance, OSIISS must pay attention to the self-management factors of a CRO who are appropriate in handling applicants, especially in service recovery efforts. The results of this study are consistent with the results of previous studies conducted by McQuilken, at al. (2020); states that, self-management has a positive and significant effect on service recovery performance.

\section{The influence of social capacity on Service recovery Performance}

The coefficient of determination or the value of R Square on the adaptive ability of the social capacity of CRO officers is 0.317, which means that the regression model obtained can explain $31.7 \%$ of the variation in the dependent variable service recovery recommendations $\mathrm{HGB}$ above HPL. The value of $t$ count on. The social capacity 25 is 4,720 . On the basis of the conditions for acceptance of $\mathrm{H} 1$ is the value of $t$ count $>t$ critical, which in this section is 4,720> 2,01063, then the first $\mathrm{H} 1$ is declared acceptable.

Based on the results of ANOVA test data processing, the significance value shows a number of 0.000 , which means that the significance value is lower than 0.050 . It can be concluded that the adaptive ability of CRO officers; Social capacity can affect service recovery performance. Obtained coefficient of determination or the value of $\mathrm{R}$ Square on the adaptive ability of CRO officers' cultural competence is 0.279 meaning that the regression model obtained can explain $27.9 \%$ of the variation in the dependent variable service recovery recommendations for HGB above HPL, therefore it can concluded that the adaptive ability of CRO officers; Social capacity has an influence on service recovery performance. The coefficient of determination or the value of $\mathrm{R}$ Square on the adaptive ability of the CRO officers' cultural competence is 0.279 , which means that the regression model obtained can explain $27.9 \%$ of the variation in the dependent variable service recovery recommendations for HGB above HPL. The social capacity of CRO officers is shown with an optimistic attitude when working with an applicant for recommendation of HGB over HPL who has failed experience in serving HGB over HPL, so there is no doubt in providing services to the applicant. This optimistic attitude makes CRO's service recovery performance better. The results of this study are consistent with the results of previous studies conducted by McQuilken, et al. (2020); stated that, social capacity has a positive and significant effect on the service recovery performance of a CRO.

\section{Effect of Informational Fairness on Service Recovery Performance}

The $\mathrm{t}$ value on the informational fairness is 1.423. On the basis of the conditions for acceptance of $\mathrm{H} 1$ is informational fairness, the value of $t$ count $>$ $t$ critical, which in this section is 1.423 $<2.01063$, then the first $\mathrm{H} 1$ is declared rejected. It can be concluded that there is no relationship between the variable of adaptive ability of CRO officers; informational fairness and variable service recovery performance.

Based on the results of ANOVA test data processing, the significance value shows a number of 0.161 , which means that the significance value is greater than 0.050 . It can be concluded that the adaptive ability of CRO officers; Informational fairness cannot affect service recovery performance. The coefficient of determination or the value of $\mathrm{R}$ Square on the adaptive ability of the CRO officers' cultural competence is 0.279 , meaning that the regression model obtained can explain $27.9 \%$ of the variation in the dependent variable service recovery recommendation HGB above HPL. The results of this study are different from the results of previous studies conducted by McQuilken, et al. (2020) and McFarlin \& Sweeney (1992) 
state that informational fairness has a positive and significant effect on service recovery performance.

\section{Effect of Self-Efficacy Recovery on Service Recovery Performance}

The coefficient of determination or the value of $\mathrm{R}$ Square on the adaptive ability of recovery self-efficacy of CRO officers is 0.599, which means that the regression model obtained can explain $59.9 \%$ of the variation in the dependent variable service recovery. it means that the regression model obtained can explain $27.9 \%$ of the variation in the dependent variable service recovery recommendations for HGB above the HPL.

The t value for recovery self-efficacy is 8.475. On the basis of the conditions for acceptance of $h 1$ is the value of $t$ count $>t$ critical, which in this section is 8,475> 2,01063 , then the first h1 can be accepted.

Based on the results of ANOVA test data processing, the significance value shows a number of 0.000 , which means that the significance value is lower than 0.050. It can be concluded that the adaptive ability of CRO officers; recovery self-efficacy can affect the service recovery performance of the HGB recommendation above the HPL. Therefore, it can be concluded that the adaptive ability of CRO officers; recovery self-efficacy has an influence on the service recovery performance of the HGB recommendation above the HPL

The results of this study are consistent with the results of previous studies conducted by (Akamavi, Mohamed, Pellmann, \& Xu, 2015); and (Smith, Fox, \& Ramirez, 2010) respectively state that selfefficacy has a positive and significant effect on service recovery performance.

\section{Effect of Organizational Recovery System on Service Recovery Performance}

The coefficient of determination or the value of R Square on the adaptive ability of the organizational recovery system for
CRO officers is 0.522 , which means that the regression model obtained can explain $52.2 \%$ of the variation in the dependent variable on service recovery recommendations recommended by HGB above HPL. Whereas the $t$ value in the organizational recovery system is 7,245 . On the basis of the conditions for acceptance of $\mathrm{H} 1$ is the value of $\mathrm{t}$ count $>\mathrm{t}$ critical, which in this section is 7,245>2,01063, then the first $\mathrm{H} 1$ can be accepted.

Based on the results of the ANOVA test data processing. The significance value shows a number of 0.000 , which means that the significance value is lower than 0.050 . It can be concluded that the adaptive ability of CRO officers; organizational recovery system can affect the service recovery performance of the HGB recommendation over the HPL. Based on the discussion, it can be concluded that $\mathrm{H} 0$ is rejected and $\mathrm{H} 1$ is acceptable, namely the implementation of the adaptive capacity of CRO officers; the organizational recovery system has an influence on the service recovery performance of the HGB recommendation above the HPL.

The results of this study are consistent with the results of previous studies conducted by (Leticia Santos - Vijande, María Díaz - Martín, Suárez - Álvarez, \& Belén del Río - Lanza, 2013) which stated that organizational recovery systems have a positive and significant effect on service recovery Performance.

\section{CONCLUSION}

Based on the description of the research results and discussion of the adaptive capability of CRO in service recovery on HGB recommendation services over HPL at the DKI Jakarta Province One Stop Integrated Service and Investment Service which is assessed from six variables, namely cultural competence, self management, informational fairness, self efficacy and organizasional recovery system, show that cultural competence, self management self efficacy and 
organizasional recovery system has positive influence on service recovery performance, while informational fairness has no relationship or influence over service recovery performance officer CRO.

\section{BIBLIOGRAPHY}

Akamavi, R. K., Mohamed, E., Pellmann, K., \& Xu, Y. (2015). Key determinants of passenger loyalty in the low-cost airline business. Tourism

Management. https://doi.org/10.1016/j.tourman.2014.07. 010

Atmadjati, A. (2018). Layanan Prima Dalam Praktik Saat Ini. Yogyakarta: Deepublish.

Gantina, K. (2011). Teori dan Teknik Konseling. Jakarta: PT. Indeks.

Indonesia. Peraturan Daerah Provinsi DKI Jakarta Nomor 12 Tahun 2013 tentang Penyelenggaraan Pelayanan Terpadu Satu Pintu. , (2013).

Kotler, P. (2017). Marketing for competitiveness. Yogyakarta: Bentang Pustaka.

Leticia Santos-Vijande, M., María Díaz-Martín, A., Suárez-Álvarez, L., \& Belén del Río-Lanza, A. (2013). An integrated service recovery system (ISRS). European Journal of Marketing. https://doi.org/10.1108/030905613113069 94

McQuilken, L., Robertson, N., Abbas, G., \& Polonsky, M. (2020). Frontline health professionals' perceptions of their adaptive competences in service recovery. Journal of Strategic
Marketing, $\quad 28(1), \quad 70-94$. https://doi.org/10.1080/0965254X.2018.15 11630

Sahadev, S., Purani, K., \& Malhotra, N. (2015). Boundary spanning elements and the marketing function in organizations. Switzerland: Springer.

Schindehutte, M., \& Morris, M. H. (2001). Understanding strategic adaptation in small firms. International Journal of Entrepreneurial Behaviour \& Research. https://doi.org/10.1108/EUM00000000055 32

Smith, J. S., Fox, G. L., \& Ramirez, E. (2010). An integrated perspective of service recovery: A sociotechnical systems approach. Journal of Service Research https://doi.org/10.1177/109467051037510 4

Sopan Adrianto, S. E. (2019). PENEROKA Kepemimpinan Sekolah. Jakarta: Elex media komputindo.

Sugiyono. (2009). Metode Penelitian Kuantitatif Kualitatif dan R\&D. Bandung: Alfabeta.

Wong, N. Y. (2004). The role of culture in the perception of service recovery. Journal of Business Research. https://doi.org/10.1016/S01482963(03)00002-X

Yusriadi. (2018). Reformasi Borokrasi Dalam Pelayanan Publik: Bureucratric Reform In Public Service. Yogyakarta: Deepublish.

Zeithaml, V. A. Bitner, M. J. (2000). Services Marketing (2nd Ed.). New York: McGraw-Hill Companies Inc. 